\title{
Mitologia codzienności, kebab i Adam Małysz
}

\section{Marcin Napiórkowski, Mitologia współczesna, Wydawnictwo Naukowe PWN, Warszawa 2018, ss. 382.}

$\mathrm{M}$ arcin Napiórkowski, semiotyk kultury i wykładowca w Instytucie Kultury Polskiej Uniwersytetu Warszawskiego, pisze na swoim blogu, że „pomaga

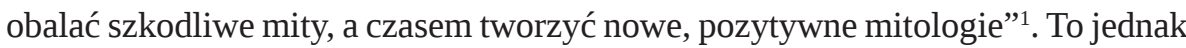
nie wszystko, Napiórkowskiemu zależy bowiem przede wszystkim na tym, by ukazać, że mitycznego myślenia nie powinniśmy dziś dostrzegać tylko u innych, ale również - a może przede wszystkim - u siebie.

We wstępie do Mitologii współczesnej badacz formułuje jasny postulat: „Spróbujmy szerzej otworzyć oczy i przyjąć punkt widzenia, zgodnie z którym nie żyjemy wcale w »świecie bez mitów«” (s. 11). Dlaczego jednak w ogóle powinniśmy się tymi mitami zajmować? Cytując autora: ponieważ „świat bez mitów byłby światem bez sensu” (s. 15), m.in. dlatego, że te „wypełniają niepostrzeżenie obszary naszej niewiedzy, stwarzając ramy do nadawania znaczeń” (s. 13). Zaznaczyć przy tym trzeba (i robi to także warszawski semiotyk), że Mitologia współczesna nie ma na celu rozstrzygania, które mity są prawdziwe, a które fałszywe. Kategorie prawdy i fałszu schodzą tu na dalszy plan, gdyż „odkrycie fałszu nie jest tutaj końcem, lecz

${ }^{1}$ Blog Mitologia współczesna, https://mitologiawspolczesna.pl/marcin-napiorkowski-semiotyk-stukturalista [20.02.2019], 
dopiero początkiem zadania. Dopiero tu pojawia się bowiem interesujące pytanie: dlaczego akurat spośród nieskończonej gamy możliwości funkcjonują akurat te fałszywe historie? Co skłania ludzi do ich powtarzania?” (s. 16).

Pewne (p)odpowiedzi pojawiają się już we wstępie do omawianej książki: dzieje się tak, gdyż w gruncie rzeczy opowieści mityczne są „współczesnymi realizacjami klasycznych opowiadań o ludzkiej pysze, końcu świata, bohaterstwie, ale też obcości, dzikości i barbarzyństwie”. Analizę mitologiczną tych współczesnych realizacji, a więc - za tytułem opracowania - współczesnych mitów, udało się przeprowadzić Napiórkowskiemu w sposób niezwykle błyskotliwy, ciekawy, interesujący, a nawet intrygujący - warto więc bardziej szczegółowo przyjrzeć się choć kilku przykładom, które badacz wziął pod lupę, oraz wnioskom, jakie ostatecznie sformułował.

Mitologia współczesna to zbiór dwunastu tekstów, które wcześniej ukazały się m.in. w „Kulturze Współczesnej”, „Zeszytach Etnologii Wrocławskiej”, „Kulturze Liberalnej” oraz „Sztuce i Filozofii”. Łączy je to, że poruszają one tematy nośne i atrakcyjne - tak z naukowego, jak i publicystycznego punktu widzenia. To historie, które tworzą naszą codzienność, a przynajmniej na co dzień nam towarzyszą. To aktywności, w których bierzemy udział, oraz informacje, którym wierzymy. To sylwetki, kariery i losy naszych idoli oraz ulubionych sportowców. I w końcu: to nasze powszechne obawy i lęki. Napiórkowski, dokonując analizy antropologicznej wybranych tematów, ukazuje to wszystko jednak w innym świetle, obnaża skrywające się za tymi popularnymi opowieściami mechanizmy, w rezultacie zaś obnaża naszą niepohamowaną potrzebę nadawania znaczeń wszystkiemu, co tworzy naszą rzeczywistość. Niejako przy okazji udowadnia natomiast, że potrzeba ta realizowana jest nie tylko tam, gdzie pojawia się niewiedza, którą łatwo wychwycić, lecz także tam, gdzie pozornie jej nie ma - i właśnie to w lekturze Mitologii współczesnej jest najbardziej frapujące.

W pierwszym artykule, zatytułowanym Muszelki i nakrętki. Dlaczego dzicy sq dzicy, a my racjonalni?, semiotyk pochyla się nad ogólnopolską charytatywną akcją zbierania nakrętek. Temat, wydawać by się mogło, błahy, jednak okazuje się, że wręcz przeciwnie. Zwłaszcza gdy zdamy sobie sprawę z tego, że motywacje osób biorących w niej udział wcale nie są tak jasne, jak wcześniej sądziliśmy. Pytań jest zresztą więcej. Napiórkowski nie zastanawia się tylko nad tym, czy nakrętki opłaca się zbierać, ale również nad tym, w jaki sposób miałyby zamieniać się w pieniądze (s. 28). Wychodząc z założenia, że „wyjaśnienia skomplikowanych zjawisk ekonomicznych krążące w społeczeństwie stanowią jeden z najciekawszych materiałów do badań nad współczesnymi mitami” (s. 28), przeprowadza śledztwo, które zaowocować ma znalezieniem satysfakcjonujących odpowiedzi. Odpowiedzi, których - dodajmy - udzielić nie potrafi nawet... Google.

Wśród cytowanych wyjaśnień proponowanych przez internautów pojawiają się najróżniejsze teorie: te, zgodnie z którymi za akcją „przemieniania” nakrętek 
w pieniądze stoją wielkie światowe koncerny, takie jak Coca-Cola czy Pepsi, albo te, według których całe przedsięwzięcie jest oszustwem, na którym ktoś zarabia (s. 29). Jak się bowiem okazuje, istotne niekoniecznie jest to, co ostatecznie uznamy za prawdę, lecz to, za pomocą jakich narracji poszukujemy wyjaśnień. Marcin Napiórkowski stara się dociec nie tego, jak naprawdę jest, lecz raczej tego, „skąd pochodzi przyjmowane wyjaśnienie” (s. 30), jak wygląda jego obieg, dlaczego wybieramy te, a nie inne uzasadnienia, a także „dlaczego racjonalni ludzie mają tendencję do powtarzania jako prawdziwych różnych zasłyszanych wyjaśnień, a nawet ręczenia za nie i spierania się o ich autentyczność” (s. 31). W rezultacie więc, jak pisze sam autor, „docieramy do jednego z najważniejszych pytań książki, do pytania o sens powtarzania i potwierdzania prawdziwości mitów” (s. 31).

Mity te są zaś najróżniejsze. Badacz odnajduje je nie tylko w opisanej akcji zbierania nakrętek, ale również w głośnych, powszechnie znanych teoriach spiskowych i legendach miejskich, które tak mocno wdarły się do naszej codzienności, że nie pytamy już o ich autentyczność. Tak jest np. z - będącymi od dawna w obiegu - opowieściami o łowcach nerek, budzącej przerażenie dorosłych, a rzekomo popularnej wśród nastolatków „zabawie w słoneczko”, kebabowym podziemiu i „pożeraczach psów”, a także z wszechobecnymi dziś fake newsami. Każdy z tych wątków omówiony został z wykorzystaniem analizy mitologicznej, co pozwoliło Napiórkowskiemu na przedstawienie wymienionych zjawisk z perspektywy antropologicznej, a dokładniej - w ujęciu strukturalistycznym. To zaś prowadzi do pogłębionych i interesujących wniosków.

Na tle wszystkich analizowanych opowieści mitycznych szczególnie ciekawa wydała mi się analiza fenomenu Adama Małysza. Dlaczego akurat ten sportowiec cieszy się tak dużą sławą i popularnością? Dlaczego tak bardzo mu kibicowaliśmy? Co sprawiło, że stał się on polskim bohaterem, dzięki któremu skoki narciarskie są wręcz dyscypliną narodową? Czy Adam Małysz jest tylko idolem? Wyłącznie wybitnym sportowcem? Napiórkowski twierdzi, że nie - według niego skoczek jest „epickim wojownikiem”, a nawet „przewodnikiem duchowym” (s. 183). I to właśnie stanowi o wartości Mitologii współczesnej - wydawać by się mogło, że książka ta stara się szokować, zaskakiwać, lecz w rzeczywistości po prostu ukazuje nam mity, które wszyscy znamy, ale z natury których wcześniej nie zdawaliśmy sobie sprawy. Mity, które otaczają nas zewsząd, które sami tworzymy i rozprzestrzeniamy, często nie wiedząc nawet, że wpadliśmy w ich pułapkę. To z kolei wskazuje na potężny walor edukacyjny omawianej tu lektury - pod przewodnictwem warszawskiego semiotyka i kierując się jego wskazówkami, możemy nie tyle uczyć się od nowa interpretowania codzienności, ile po prostu podchodzić do niej - i do samych siebie - bardziej uważnie. Zdaje się bowiem, że pośrednim celem Mitologii współczesnej, który uważam zresztą za najbardziej atrakcyjny, jest zainspirowanie czytelnika do tego, by sam został tropicielem mitów. 
Na uwagę zasługuje również sposób, w jaki Napiórkowski przeprowadza oraz relacjonuje swoje „dochodzenia” - dociekliwy, erudycyjny, nierzadko dowcipny. To już nie tylko rzetelny tekst akademicki, to również zajmujący, pasjonujący storytelling, pełen zaskakujących zwrotów akcji, dzięki któremu Mitologia współczesna ma podwójną wartość: naukową i popularyzatorską. Choć jest to pozycja merytoryczna, doskonale dopracowana pod względem metodologicznym, jej narracja jest płynna i sprawia, że całość czyta się szybko, z emocjami towarzyszącymi przy lekturze... dobrego kryminału.

Ta cecha oczywiście może być odebrana dwojako - według mnie jest ogromną zaletą książki, choć zdaję sobie sprawę, że równie dobrze można przekuć ją w zarzut. Uważam jednak, że niesłusznie, ponieważ właśnie tym powinny cechować się dobre opracowania naukowe: być rzeczowe, ale przystępne, aby badacz do swojej pasji mógł przekonać jak największe grono odbiorców. Marcinowi Napiórkowskiemu przychodzi to niejako naturalnie, co tym bardziej zasługuje na docenienie. Gdybym natomiast miała wskazać, co w moim przekonaniu zasługuje na pogłębienie, wymieniłabym same analizy. Nie dlatego, że są uproszczone czy niepełne, ale dlatego, że po przeczytaniu każdego artykułu pojawia się lekki niedosyt. Oto bowiem skończyliśmy przygodę ze śledztwem, które nadal chcielibyśmy prowadzić. Zachęcam więc, w imieniu swoim i Marcina Napiórkowskiego, by czynić to w oparciu o bloga Mitologia współczesna, a także własne doświadczenia. 